\title{
Anatomical and physiological aspects of cucumber graft
}

\author{
Daniel Baron 1*, Gustavo Francisco Rosalin Saraiva², Talita Silveira Amador ${ }^{3}$, \\ João Domingos Rodrigues ${ }^{3}$, Rumy Goto ${ }^{3}$, Elizabeth Orika Ono ${ }^{3}$
}

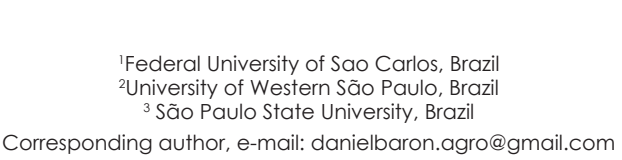

\begin{abstract}
The grafting of two cucumber scions (Cucumis sativus L.) - Taiko hybrid and Tsuyoi hybridonto a Tropical hybrid pumpkin rootstock (Cucurbita moschata L.) was studied. The study was conducted in a greenhouse. Plants grafted using the tongue approach grafting technique were compared with ungrafted plants. We evaluated the initial establishment of grafting through anatomical cuts on the region of union graft and examining leaves' chlorophyll index (SPAD) and their levels of chlorophyll $a$, chlorophyll $b$ and total chlorophyll. The experimental design utilized randomized blocks and the data were subjected to variance analysis (ANOVA) and the Tukey Test at $5 \%$ probability. The results indicate that Taiko cucumber scions are best grafted onto Tropical pumpkin rootstock, since these exhibits early grafting establishment. Moreover, when compared to grafting using Tsuyoi cucumber scions, Taiko cucumber scions present higher SPAD index values and levels of chlorophyll a and total chlorophyll.
\end{abstract}

Keywords: Cucurbitaceae, chlorophyll, plant anatomy, plant propagation

\begin{abstract}
Cucumbers are used mainly in food, with
further applications in health and beauty products, including perfumes, lotions, and shampoos (Patil et al., 2012; Pimenta-Lange et al., 2013). The use of rootstock increases productivity by improving plants' capacity to absorb soil nutrients; raising their tolerance to low soil temperatures, salinity and waterlogged soils; and preventing infection by soil-borne pathogens (Martínez-Balesta et al., 2010; Savvas et al., 2010). The grafting of cucumber onto pumpkin (Cucurbita moschata Duch.), squash (Cucurbita maximum Schrad.), or hybrid pumpkins is undertaken by many producers to take advantage of the greater root development and hardiness of some pumpkins
\end{abstract}

(Karaağaç \& Balkaya, 2013; Savvas et al., 2013). Compatibility is defined as the ability of two different plants to coexist satisfactorily as a single plant after grafting. There is no method for predicting the graft outcome; however, in general, there is greater affinity within botanical species and consequently a higher probability of graft survival (Hartmann et al., 2011). This affinity involves both morphological and physiological plant aspects. Morphological, anatomical and tissue constitution refer to the conductive vessels of two plants that are of similar diameters and approximately equal in number (Pina et al., 2009), while physiological affinity relates to the amount and composition of the sap (Etehadnia et al., 
2008; Aloni et al., 2010; Savvas et al. 2013).

The outer layers exposed in the cambium region, in both the graft and the rootstock, produce parenchyma cells that mix and interweave, forming what is commonly called callus tissue. In this callus tissue, cells that align with the intact cambium and graft rootstock differentiate into new foreign cells, which is a pre-requisite for the successful union of vascular plants (Hartmann et al., 2011). The present paper aimed to examine the early biological processes that occur in graft union with the rootstock, based on an anatomical and physiological evaluation of two varieties of cucumber plants grafted onto pumpkin rootstock.

The site of the experiment was the Faculdade de Ciências Agronômicas (FCA), Universidade Estadual Paulista (Unesp), Botucatu campus. We used an arc type greenhouse $30 \mathrm{~m}$ in length, $7 \mathrm{~m}$ in width and $3 \mathrm{~m}$ in height, covered

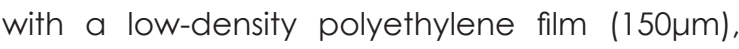
with the lateral sides covered with a $75 \%$ shade cloth. Pumpkin seeds (Cucurbita moschata Dusch.), "Tropical" hybrid (SAKATA®), and cucumber seeds (Cucumis sativus L.), "Taiko" hybrid (SAKATA®) and "Tsuyoi" hybrid (TAKII Seed(B), were sown on polystyrene trays filled with a commercial substrate containing a mixture of pine bark, compost, vermiculite, and fertilizers. To ensure that both hypocotyl diameters were similar, to allow for proper grafting, the pumpkin was sown four days before the cucumber.

The Taiko and Tsuyoi cucumber scions were grafted onto Tropical pumpkin rootstock using the tongue approach grafting method (Peil, 2003). Four days after grafting, the plants were transplanted to plastic pots with a volumetric capacity of $400 \mathrm{~mL}$, filled with the same substrate used in sowing, and kept in a moist chamber until suitable for transplantation. We performed the grafting 10 days after sowing the cucumber and evaluated five treatments with 15 plants each: T1- Tropical pumpkin, ungrafted; T2 - Taiko cucumber, ungrafted; T3 - Tsuyoi cucumber, ungrafted; T4 - Taiko cucumber scion grafted onto Tropical pumpkin rootstock; and T5 - Tsuyoi cucumber scion grafted onto Tropical pumpkin rootstock.

Anatomical studies evaluated the stem region where the graft was performed based on a light microscopic examination of crosssections, in accordance with Buskatsch (1972). Chlorophyll analyses were performed on mature leaves, in accordance with Sims and Gamom (2002). The chlorophyll index was evaluated in the central region of the leaf using the Minolta chlorophyll meter SPAD-502R® in SPAD units. The experimental design was randomized, and the results obtained were subjected to variance analysis (ANOVA). The averages were compared by Tukey Test at 5\% ( $p \leq 0.05)$ probability.

The results of the anatomical study revealed that the Taiko cucumber scion grafted onto pumpkin rootstock showed earlier establishment of the graft compared to the Tsuyoi cucumber scion grafted onto pumpkin rootstock (Figure 1). According to Kawaguchi et al. (2008), incompatibility manifests in several ways, the most important of which is a break of grafting region. The filling of spaces by parenchyma cells (callus tissue) was more effective on Taiko cucumber scions grafted onto pumpkin rootstock (Figures 1A). Pina et al. (2012) reported that the parenchymal tissue plays an important role, since it promotes the initial connection or bond between the graft and rootstock. Thus, the larger the contact surface between the parenchyma cells of both plants, the greater the likelihood of a successful graft (Aloni et al., 2010).

The chlorophyll a, chlorophyll b, and total chlorophyll content varied significantly between treatments, with the highest chlorophyll a and total chlorophyll values appearing in T1, T3 and T4 (Table 1). The highest chlorophyll b values were found in the plants in T4, but these did not differ from the other treatments, except those presented in ungrafted Taiko cucumber.

According to Martínez-Ballesta et al. (2010), a vigorous rootstock can provide greater vigor and development, leading to improved translocation of nutrients by conducting vessels, although in the present study only a single species was used as rootstock. Several studies point to differences in the absorption of nutrients in grafted plants and the fact that these nutrients are restricted in the graft region during graft healing and vascular connection (Colla et al., 2012; Borgognone et al., 2013). Among these 


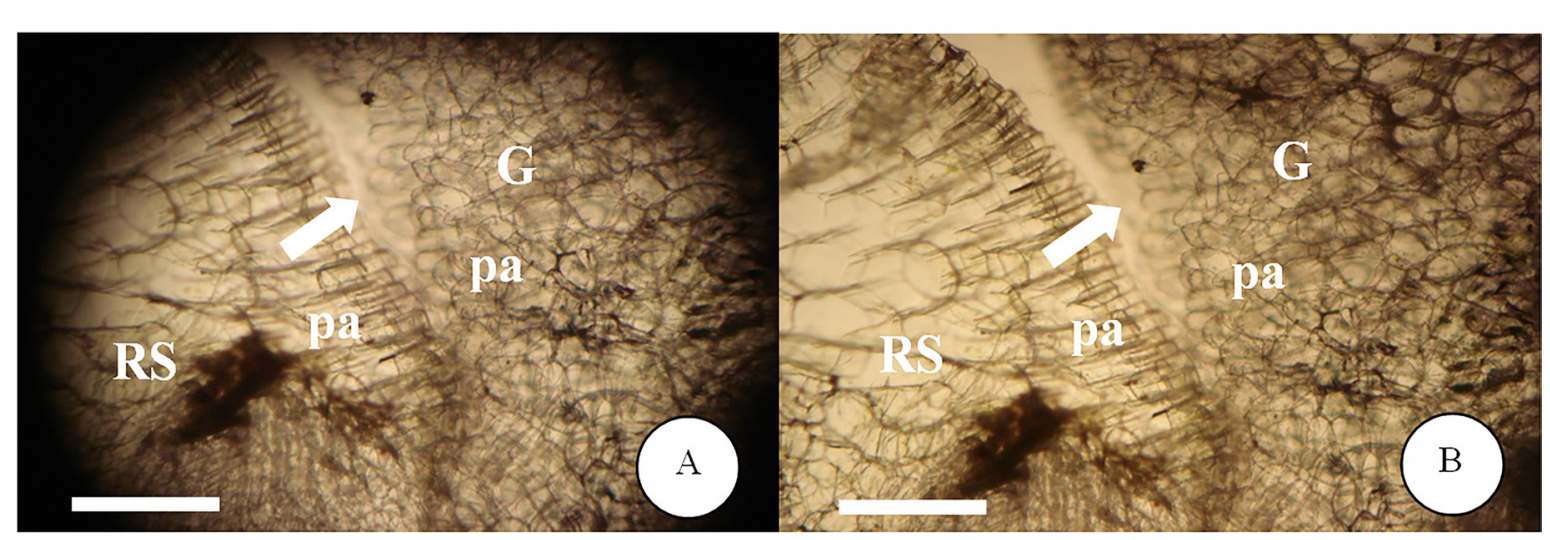

Figure 1. Histological sections of the graft region. A: The cross-sections of the stem epidermis of Taiko cucumber scion grafted onto Tropical pumpkin rootstock; B: The cross-sections of the stem epidermis of Tsuyoi cucumber scion grafted onto Tropical pumpkin rootstock. $\mathrm{Pa}=$ parenchyma; $\mathrm{G}=$ graft; $\mathrm{RS}=$ rootstock; $\mathrm{Bar}=150 \mu \mathrm{m}$.

Table 1. Levels of chlorophyll a, chlorophyll b, and total chlorophyll in the leaves of Tropical pumpkin and Taiko and Tsuyoi cucumber plants, both grafted and ungrafted.

\begin{tabular}{|c|c|c|c|}
\hline Treatment & $\begin{array}{l}\text { Chlorophyll a } \\
\left(\mathrm{mg}^{\left.-g^{-1}\right)}\right.\end{array}$ & $\begin{array}{l}\text { Chlorophyll b } \\
\left(\mathrm{mg}^{\left.-g^{-1}\right)}\right.\end{array}$ & $\begin{array}{c}\text { Chlorophyll total } \\
\left(\mathrm{mg}^{\left.-\mathrm{g}^{-1}\right)}\right.\end{array}$ \\
\hline T1 - Tropical pumpkin, ungrafted & $0.0287 a$ & $0.0129 a b$ & 0.0416 a \\
\hline T2 - Taiko cucumber, ungrafted & $0.0211 \mathrm{c}$ & $0.0098 \mathrm{~b}$ & $0.0309 \mathrm{~b}$ \\
\hline T3 - Tsuyoi cucumber, ungrafted & $0.0269 \mathrm{ab}$ & $0.0158 \mathrm{ab}$ & $0.0428 a$ \\
\hline $\begin{array}{l}\text { T4 - Taiko cucumber scion grafted } \\
\text { onto Tropical pumpkin rootstock }\end{array}$ & $0.0285 \mathrm{a}$ & $0.0164 \mathrm{a}$ & $0.0450 a$ \\
\hline $\begin{array}{l}\text { T5 - Tsuyoi cucumber scion grafted } \\
\text { onto Tropical pumpkin rootstock }\end{array}$ & $0.0236 \mathrm{bc}$ & $0.0111 \mathrm{ab}$ & $0.0309 \mathrm{~b}$ \\
\hline & \multicolumn{3}{|c|}{ ANOVA (chlorophyll a) } \\
\hline 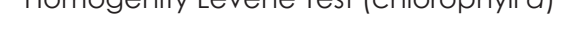 & \multicolumn{3}{|c|}{$C V(\%)=5.77$} \\
\hline$F$ Value $=0.76$ & \multicolumn{3}{|c|}{$F$ Value $=10.20$} \\
\hline $\operatorname{Pr}>F=0.5759^{*}$ & \multicolumn{3}{|c|}{$\operatorname{Pr}>F=0.0022^{* *}$} \\
\hline & \multicolumn{3}{|c|}{ ANOVA (chlorophyll b) } \\
\hline 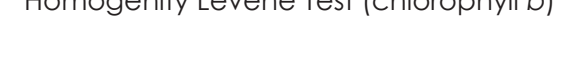 & \multicolumn{3}{|c|}{$\mathrm{CV}(\%)=22.07$} \\
\hline F Value $=3.09$ & \multicolumn{3}{|c|}{$F$ Value $=2.14$} \\
\hline $\operatorname{Pr}>F=0.0674^{*}$ & \multicolumn{3}{|c|}{$\operatorname{Pr}>F=0.1582^{* *}$} \\
\hline & \multicolumn{3}{|c|}{ ANOVA (chlorophyll total) } \\
\hline 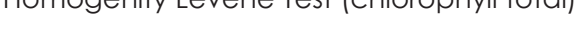 & \multicolumn{3}{|c|}{$C V(\%)=6.06$} \\
\hline$F$ Value $=2.81$ & \multicolumn{3}{|c|}{$F$ Value $=13.17$} \\
\hline $\operatorname{Pr}>F=0.0845^{*}$ & \multicolumn{3}{|c|}{$\operatorname{Pr}>F=0.009^{* *}$} \\
\hline
\end{tabular}

nutrients, magnesium (Mg) and nitrogen $(\mathrm{N})$ are extremely important in the formation of the chlorophyll molecule (Taiz \& Zeiger, 2013). This could be directly responsible for the higher chlorophyll a and total chlorophyll content present in Taiko cucumber plants grafted onto pumpkin rootstock. Photosynthetic pigments are indicators of stress in plants, so estimating the leaf chlorophyll content of grafted plants with the SPAD-502R holds the potential to diagnose the nutritional status of the plant under stress (Table 2).

We concluded that Taiko cucumber scions are best grafted onto Tropical pumpkin 
Table 2. Chlorophyll index (SPAD) in the leaves of Tropical pumpkin and Taiko and Tsuyoi cucumber in both grafted and ungrafted plants

\begin{tabular}{|c|c|}
\hline Treatment & Chlorophyll index (SPAD) \\
\hline T1 - Pumpkin 'Tropical' ungrafted & $35.2 a b$ \\
\hline T2 - Cucumber 'Taiko' ungrated & $35.28 a b$ \\
\hline T3 - Cucumber 'Tsuyoi' ungrafted & $41.39 a$ \\
\hline $\begin{array}{l}\text { T4 - Cucumber 'Taiko' scion grafted } \\
\text { onto pumpkin 'Tropical' rootstock }\end{array}$ & $32.44 b$ \\
\hline $\begin{array}{l}\text { T5 - Cucumber 'Tsuyoi' scion grafted } \\
\text { onto pumpkin 'Tropical' rootstock }\end{array}$ & $36.10 \mathrm{ab}$ \\
\hline $\begin{array}{l}\text { Homogenity Levene Test (chlorophyll index) } \\
\qquad \begin{array}{l}F \text { Value }=1.86 \\
\text { Pr }>F=0.1695^{*}\end{array}\end{array}$ & $\begin{array}{l}\text { ANOVA (SPAD) } \\
C \vee(\%)=14.44 \\
F \vee \text { alue }=1.48 \\
\operatorname{Pr}>F=0.2619^{* *}\end{array}$ \\
\hline
\end{tabular}

the column do not differ significantly by the mean comparison test.

rootstock, since they show early grafting establishment when compared to the grafting of Tsuyoi cucumber scions. They also present higher SPAD index values and chlorophyll a and total chlorophyll content.

\section{References}

Aloni, B., Cohen, R., Karni, L., Aktas, H., Edelstein M. 2010. Hormonal signaling in rootstock-scion interactions. Scientia Horticulture 27:1 19-126.

Borgognone, D., Colla, G., Rouphael, Y., Cardarelli, M., Rea, E., Schwarz, D. 2013. Effect of nitrogen form and nutrient solution $\mathrm{pH}$ on growth and mineral composition of self-grafted and grafted tomatoes. Scientia Horticulturae 149: 6169.

Buskatsch, F. 1972. Bemerkungen zur Doppelfärbung, Astrablau-Safranin. Mikrokosmos 6: 255-255.

Colla, G., Rouphael, Y., Rea, E., Cardarelli, M. 2012. Grafting cucumber plants enhance tolerance to sodium chloride and sulfate salinization 2012. Scientia Horticulturae 135:177-185.

Ełehadnia, M., Waterer, D., De Jong, H., Tanino, K.K. 2008. Scion and rootstock effects on ABAmediated plant growth regulation and salt tolerance of acclimated and unacclimated potato genotypes. Journal of Plant Growth Regulation 27:125-140.

Hartmann, H.T.; Kester, D.E.; Davies, F.T.; Geneve, R. 2011. Plant Propagation: Principles and Practices. 8.ed. Prentice Hall, New York, USA. 912 p.

Karaağaç, O., Balkaya, A. 2013. Interspecific hybridization and hybrid seed yield of winter squash (Cucurbita maxima Duch.) and pumpkin
(Cucurbita moschata Duch.) lines for rootstock breeding. Scientia Horticulturae 149:9-12.

Kawaguchi, M., Taji, A., Backhouse, D., Oda, M. 2008. Anatomy and physiology of graft incompatibility in solanaceous plants. Journal of Horticulture Science and Biotechnology 83:581588.

Martínez-Ballesta, M.C., Alcaraz-López, C., Muries, B., Mota-cadenas, C., Carvajal, M. 2010. Physiological aspects of rootstock-scion interactions. Scientia Horticulturae 127:112-118.

Patil, M.V.K, Kandhare, A.D., Bhise, S.D. 2012. Effect of aqueous extract of Cucumis sativus Linn. fruit in ulcerative colitis in laboratory animals. Asian Pacific Journal of Tropical Biomedicine 2:962-969

Peil, R.M. 2003. Grafting of vegetable crops. Ciência Rural 33:1169-1177.

Pimenta-Lange, M.J., Liebrandt, A., Arnold, L., Chmielewska, S.M., Felsberger, A., Freier, E., Hever, M., Zur, D., Lange, T. 2013. Functional characterization of gibberellin oxidases from cucumber, Cucumis sativus L. Phytochemistry 90:62-69.

Pina, A., Errea, P., Schulz, A., Martens, H.J. 2009. Cell-to-cell transport through plasmodesmata in tree callus cultures. Tree Physiology 29:809-818.

Pina, A., Errea, P., Martens, H.J. 2012. Graft union formation and cell-to-cell communication via plasmodesmata in compatible and incompatible stem unions of Prunus spp. Scientia Horticulturae 143:144-150.

Savvas, D., Colla, G., Rouphael, Y., Schwarz, D. 2010. Amelioration of heavy metal and nutrient stress in fruit vegetables by grafting. Scientia 
Horticulturae 127:156-161.

Savvas, D., Ntatsi, G., Barouchas, P. 2013. Impact of grafting and rootstock genotype on cation uptake by cucumber (Cucumis sativus L.) exposed to Cd or Ni stress. Scientia Horticulturae 149:86-96.

Sims, D.A., Gamon, J.A. 2002. Relationships between leaf pigment content and spectral reflectance across a wide range of species, leaf structures and developmental stages. Remote Sensing of Environment 81: 337-354.

Taiz, L., Zeiger, E. 2013. Plant physiology. 5.ed. Porto Alegre: Artmed. 918p. 